\title{
POST-OPERATIVE HÆMORRHAGE AND RELATED ABNORMALITIES OF BLOOD COAGULATION IN CYANOTIC CONGENITAL HEART DISEASE
}

\author{
BY \\ JANE SOMERVILLE, LAWSON McDONALD, AND MARION EDGILL \\ From the Institute of Cardiology, National Heart Hospital, London W.1 \\ Received July 14, 1964
}

An abnormal tendency to post-operative hæmorrhage may occur in patients with severe cyanotic congenital heart disease (Blalock, 1948). In preliminary findings by Somerville and McDonald (1960) the thromboplastin generation test showed evidence of defective blood coagulation in these patients. Blood coagulation has been further investigated in patients with cyanotic and acyanotic congenital heart disease, and in patients with polycythæmia from other causes.

\section{SubJeCTS AND Methods}

Blood coagulation was studied in the following groups of patients: 40 with cyanotic and 10 with acyanotic congenital heart disease, 7 with polycythæmia rubra vera, 6 with cor pulmonale, and 9 normal people. The age, sex, and diagnosis in the patients with cyanotic congenital heart disease are shown in Table I: 31 cyanotic patients had Fallot's tetralogy, 2 had tricuspid atresia, 3 had pulmonary stenosis and reversed interatrial shunt, and 4 had transposition of the great vessels and pulmonary stenosis. Six of the patients with acyanotic congenital heart disease had atrial septal defect and 4 had ventricular septal defect. Patients with raised pulmonary vascular resistance were excluded from this study, for they may show a tendency to hypercoagulability of the blood (L. McDonald, J. Somerville, and M. Edgill, 1960, unpublished data). Twelve of the patients with cyanotic congenital heart disease were matched either with a patient who had acyanotic congenital heart disease or with a normal person of the same sex and similar age, or both. Blood tests were carried out in each patient at the same time of day. All patients were studied at 9.30 a.m. under uniform conditions after a low fat breakfast; $30-40 \mathrm{ml}$. of venous blood was drawn from an arm vein into an oiled syringe.

Hæmoglobin (Haldane Standard), packed cell volume, prothrombin time, platelet count, platelet stickiness, and fibrinogen were estimated, and the thromboplastin generation test (Biggs and Douglas, 1953) was performed as described by McDonald and Edgill (1958). In this test, a chloroform extract of human brain was used instead of a platelet suspension. Russell's-viper venom (Stypven) or a saline extract of acetonedried brain (Thrombokinase-Geigy) was used as the thromboplastin component in the prothrombin time estimation. Platelet stickiness was measured at 20 minutes by McDonald and Edgill's (1958) modification of Wright's method (1941). The bleeding time was measured as described by Biggs and Macfarlane (1957a), using Ivy's technique. Warren and Wysocki's modification (1958) of Lee and White's method (1913) was used to estimate the whole blood clotting time.

In patients with central cyanosis and secondary polycythæmia the packed cell volume was high, and the plasma volume appeared to be reduced. To compensate for the apparent reduction in plasma volume, the amount of citrate added for the thromboplastin generation test was adjusted so that there was not a disproportionate amount of citrate in the plasma. The amount added was such that a final concentration of plasma, citrated 1 in 10, was achieved. Assuming the normal packed cell volume to be 46, using Wintrobe 
tubes, and that $1 \mathrm{ml}$. of 3.8 per cent $\mathrm{w} / \mathrm{v}$ trisodium citrate was added to $9 \mathrm{ml}$. of blood, then to make the correction in a patient with a packed cell volume of $75,1 \times \frac{46}{75} \mathrm{ml}$. of 3.8 per cent w/v trisodium citrate was added to $10 \mathrm{ml}$. of whole blood.

In order to decide whether the cause of impaired thromboplastin generation lay in the plasma or serum, plasma and serum components were assayed separately in 13 patients, using the thromboplastin generation test. The following systems were used: (i) patient's adsorbed plasma component + normal serum component +chloroform extract of human brain + normal plasma substrate; (ii) patient's adsorbed plasma component + normal serum component + chloroform extract of human brain + patient's plasma substrate; (iii) patient's serum component+normal adsorbed plasma component+chloroform extract of human brain +normal plasma substrate; (iv) the completely normal system, i.e. the above but using serum from a control instead of the patient's serum.

Antihæmophilic-globulin (Factor VIII) was assayed in 9 patients with cyanotic congenital heart disease and 10 normal people, using the method described by Biggs and Macfarlane (1962a).

In one patient (No. 6), who was found to have grossly depressed thromboplastin generation, an extensive search was made for the site of the clotting defect. The following additional tests of blood coagulation were performed: a two-stage prothrombin time (Biggs and Macfarlane, 1957b), quantitative and qualitative tests for Factor V deficiency (Biggs and Macfarlane, 1957c), prothrombin consumption test (Biggs and Macfarlane, 1957d), thrombin generation (Pitney and Dacie, 1953), and a test for an inhibitor of plasma thromboplastin, using the qualitative method described by Biggs and Macfarlane (1962b).

\section{RESULTS}

In normal people and patients with acyanotic congenital heart disease no abnormality was found in the blood. The normal packed cell volume has been accepted as 40-54 per cent in men and 36-47 per cent in women (Dacie, 1956). Of the 40 patients with cyanotic congenital heart disease, 34 had packed cell volumes above 54 per cent; in the patients with cor pulmonale the packed cell volumes ranged from 41 to 67 per cent, and in those with primary polycythæmia, from 50 to 66 per cent. The hæmoglobin levels and red cell counts behaved similarly. Hæmoglobin, red cell counts, and packed cell volumes were highest in the most severely cyanosed patients. Whole blood clotting times were within the normal range in all the cyanotic patients except two; one was slightly prolonged, and the other slightly shortened. The bleeding times showed gross variation, and the method was considered too inaccurate for critical analysis. Only one cyanotic patient (No. 6) had a significantly prolonged prothrombin time, which occurred in the one-stage and two-stage prothrombin estimations. Four patients with cyanotic congenital heart disease $(10,19,22$, and 31$)$ had abnormally low platelet stickiness; in two of them thromboplastin generation was high for the group, and in the other two it was unusually depressed. The normal platelet count was taken as $175,000-375,000 / \mathrm{c}$. mm. of whole blood. Of the 40 cyanotic patients, 23 had low platelet counts ranging from $82,000-171,000 / \mathrm{c}$. mm. of whole blood (Table I). Plasma fibrinogen was below average in 22 patients and below normal limits in a further 4 cyanotic subjects.

Table II shows the results of the thromboplastin generation test in 12 patients with cyanotic congenital heart disease, also in 8 patients with acyanotic heart disease, and 7 normal people of the same sex and similar age, who were studied at the same time (two other normal people were studied, whose thromboplastin generation was similar to those shown in Table II). Thromboplastin generation in a further 28 patients (Table II) with cyanotic congenital heart disease behaved in a similar manner to the others.

In our laboratory the peak achieved in the thromboplastin generation test in normal subjects has been 85-122 per cent (McDonald and Edgill, 1959); in the present study the normals varied from 88-110 per cent. A figure of less than 80 per cent is therefore considered abnormally low. Fifteen cyanotic patients had normal thromboplastin generation, achieving a peak above 80 per cent; 6 had readings of $70-80$ per cent; these were estimated without correction for citrate concentration and must therefore be considered possibly to be within normal limits. Nineteen cyanotic patients achieved peaks of 17 to 69 per cent; this represents considerable impairment of thromboplastin 
TABLE I

Age, Sex, Diagnosis, Hamoglobin, Packed Cell Volume, Fibrinogen, Platelet Count, Platelet Stickiness, and Peak Thromboplastin Generation Percentage in Patients with Cyanotic Congenital Heart

DiSEASE

\begin{tabular}{|c|c|c|c|c|c|c|c|c|}
\hline \multicolumn{2}{|c|}{$\begin{array}{l}\text { Patient No., } \\
\text { sex, and age } \\
\text { (yr.) }\end{array}$} & Diagnosis & $\mathrm{Hb}(\%)$ & P.C.V. $(\%)$ & $\begin{array}{l}\text { Fibrinogen } \\
\text { ml. in } 2 \mathrm{ml} . \\
\text { plasma }\end{array}$ & $\begin{array}{l}\text { Platelets/c. } \\
\text { mm. whole } \\
\text { blood in } \\
\text { thousands }\end{array}$ & $\begin{array}{c}\text { Platelets } \\
\text { stickiness } \\
(\% \text { remain- } \\
\text { ing at } \\
20 \mathrm{~min} .)\end{array}$ & $\begin{array}{c}\text { Peak } \\
\text { thrombo- } \\
\text { plastin } \\
\text { generation } \\
(\%)\end{array}$ \\
\hline $\begin{array}{rr}1 & 1 \\
2 & 1 \\
3 & 1 \\
5 & 1 \\
6 & 1 \\
7 & 1 \\
8 & 1 \\
9 & 1 \\
10 & 1 \\
11 & 1 \\
12 & 1 \\
14 & 1 \\
15 & 1 \\
16 & 1 \\
17 & 1 \\
18 \\
19 \\
20 \\
21 \\
22 \\
23 \\
24 \\
25 \\
26 \\
27 \\
28 * \\
29 & 1 \\
30 & 1 \\
31 & 1 \\
32 & 1 \\
33^{*} & 1 \\
34 & 1 \\
35 & 1 \\
36^{*} & 1 \\
37^{*} & 1 \\
38^{*} & 1 \\
39 & 1 \\
40^{*} & 1\end{array}$ & $\begin{array}{ll}\mathbf{F} & 1 \\
\mathbf{M} & \mathbf{4} \\
\mathbf{M} & \\
\mathbf{F} & 4 \\
\mathbf{M} & 5 \\
\mathbf{M} & 16 \\
\mathbf{M} & 17 \\
\mathbf{M} & \\
\mathbf{M} & 20 \\
\mathbf{M} & \\
\mathbf{M} & 23 \\
\mathbf{M} & \\
\mathbf{F} & 17 \\
\mathbf{M} & 3 \\
\mathbf{M} & 28 \\
\mathbf{F} & 38 \\
\mathbf{M} & 3 \\
\mathbf{M} & \\
\mathbf{M} & 5 \\
\mathbf{M} & 27 \\
\mathbf{M} & 11 \\
\mathbf{M} & 32 \\
\mathbf{M} & 17 \\
\mathbf{M} & 11 \\
\mathbf{F} & 17 \\
\mathbf{M} & 36 \\
\mathbf{M} & 21 \\
\mathbf{M} & 16 \\
\mathbf{F} & 17 \\
\mathbf{F} & 20 \\
\mathbf{M} & 2( \\
\mathbf{F} & 29 \\
\mathbf{M} & \mathbf{F} \\
\mathbf{F} & 1 \\
\mathbf{F} & 4 \\
\mathbf{M} & 18 \\
\mathbf{M} & 12 \\
\mathbf{M} & 18 \\
\mathbf{M} & 18 \\
\mathbf{F} & 1\end{array}$ & 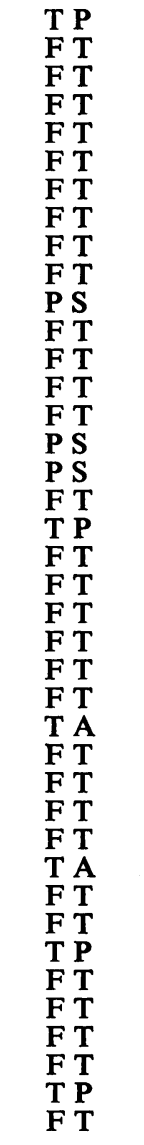 & $\begin{array}{l}151 \\
142 \\
102 \\
154 \\
142 \\
155 \\
104 \\
128 \\
110 \\
129 \\
151 \\
150 \\
124 \\
96 \\
122 \\
158 \\
121 \\
121 \\
146 \\
120 \\
146 \\
133 \\
150 \\
169 \\
154 \\
153 \\
146 \\
145 \\
142 \\
150 \\
161 \\
150 \\
160 \\
135 \\
149 \\
180 \\
124 \\
142 \\
-\end{array}$ & $\begin{array}{l}73 \\
59 \\
47 \\
69 \\
65 \\
83 \\
45 \\
58 \\
48 \\
60 \\
70 \\
70 \\
59 \\
46 \\
58 \\
73 \\
53 \\
55 \\
73 \\
54 \\
66 \\
56 \\
69 \\
81 \\
74 \\
74 \\
67 \\
68 \\
71 \\
75 \\
80 \\
79 \\
72 \\
78 \\
62 \\
78 \\
85 \\
84 \\
69 \\
60\end{array}$ & $\begin{array}{l}0.04 \\
0.08 \\
0.05 \\
0.05 \\
0.08 \\
0.05 \\
0.08 \\
0.04 \\
0.06 \\
0.08 \\
0.05 \\
0.05 \\
0.08 \\
0.05 \\
0.06 \\
0.05 \\
0.03 \\
0.05 \\
0.04 \\
0.05 \\
0.03 \\
0.04 \\
0.05 \\
0.04 \\
0.04 \\
0.05 \\
0.06 \\
0.06 \\
0.06 \\
0.05 \\
0.04 \\
0.04 \\
0.04 \\
0.04 \\
0.04 \\
0.045 \\
0.04 \\
0.04 \\
0.06 \\
0.04\end{array}$ & $\begin{array}{r}153 \\
254 \\
260 \\
148 \\
119 \\
116 \\
326 \\
206 \\
327 \\
186 \\
152 \\
253 \\
201 \\
163 \\
197 \\
195 \\
193 \\
361 \\
87 \\
171 \\
214 \\
102 \\
249 \\
127 \\
124 \\
160 \\
193 \\
123 \\
216 \\
152 \\
101 \\
82 \\
110 \\
134 \\
203 \\
130 \\
139 \\
114 \\
151 \\
126\end{array}$ & $\begin{array}{l}77 \\
77 \\
74 \\
68 \\
84 \\
78 \\
86 \\
71 \\
49 \\
61 \\
63 \\
89 \\
73 \\
65 \\
65 \\
90 \\
76 \\
35 \\
82 \\
82 \\
50 \\
77 \\
95 \\
68 \\
82 \\
74 \\
85 \\
78 \\
87 \\
49 \\
72 \\
- \\
- \\
- \\
- \\
- \\
-\end{array}$ & $\begin{array}{c}40 \\
50 \\
100 \\
22 \\
98 \\
19 \\
100 \\
88 \\
100 \\
88 \\
34 \\
40 \\
75 \\
100 \\
75 \\
83 \\
88 \\
124 \\
18 \\
127 \\
75 \\
70 \\
60 \\
35 \\
25 \\
35 \\
82 \\
70^{*} \\
75 \\
90 \\
17 \\
25 \\
45^{*} \\
21 \\
90 \\
68^{*} \\
65^{*} \\
114^{*} \\
65 \\
65^{*}\end{array}$ \\
\hline Norr & Ia & $\begin{array}{l}\text { simum } \\
\text { rage } \\
\text { imum }\end{array}$ & $\begin{array}{r}110 \\
100 \\
92\end{array}$ & $\begin{array}{l}48 \\
46 \\
42\end{array}$ & $\begin{array}{l}0.08 \\
0.06 \\
0.04\end{array}$ & $\begin{array}{l}325 \\
258 \\
211\end{array}$ & & \\
\hline
\end{tabular}

F T = Fallot's tetralogy; P S = Pulmonary stenosis with reversed interatrial shunt; $\mathrm{T} P=$ Transposition; $\mathrm{T}$ A=Tricuspid atresia.

* Correction made for concentration of citrate; see text.

generation. Typical thromboplastin generation curves from a normal person and a cyanotic patient tested at the same time are shown in Fig. 1. In the cyanotic patient, in whom the citrate concentration was corrected as described, the peak was delayed and the maximum achieved was 30 per cent at 12 and 13 minutes, compared with 95 per cent reached at 6 to 9 minutes in the normal. When the peak percentage of thromboplastin generation achieved in the test was related to the 
TABLE II

Thromboplastin Generation in Patients with Cyanotic and Acyanotic Congenital Heart Disease and Normal PeOple

\begin{tabular}{|c|c|c|c|c|c|c|c|c|c|c|c|c|c|c|c|c|c|c|}
\hline \multicolumn{4}{|c|}{ Subject } & \multicolumn{15}{|c|}{ Per cent thromboplastin at incubation times (min.) } \\
\hline & & & & 1 & 2 & 3 & 4 & 5 & 6 & 7 & 8 & 9 & 10 & 11 & 12 & 13 & 14 & 15 \\
\hline & Cyanotic & . & $\cdots$ & 1 & 1 & 1 & 2 & 3 & 7 & 35 & 40 & 40 & 35 & 32 & 24 & 19 & - & - \\
\hline \multirow[t]{2}{*}{1} & $\begin{array}{l}\text { Acyanotic } \\
\text { Normal }\end{array}$ & $\because$ & $\because$ & 1 & 2 & 13 & 110 & 110 & 110 & 105 & 100 & 100 & 100 & 98 & 88 & - & - & - \\
\hline & Cyanotic & $\because$ & $\begin{array}{l}\cdots \\
\ldots\end{array}$ & $\overline{1}$ & 1 & 2 & 4 & 5 & 16 & 45 & 50 & 50 & 43 & 40 & 35 & $\overline{28}$ & 二 & - \\
\hline \multirow[t]{3}{*}{2} & Acyanotic & .. & .. & 1 & 2 & 2 & 2 & 3 & 20 & 43 & 98 & 98 & 95 & 88 & 82 & 75 & - & 二 \\
\hline & $\mathbf{N}$ & .. & .. & 1 & 1 & 1 & 1 & 5 & 35 & 88 & 88 & 82 & 80 & 75 & 65 & - & - & \\
\hline & Cyanotic & .. & .. & 2 & 3 & 13 & 60 & 100 & 100 & 98 & 95 & 90 & 82 & 75 & 65 & - & - & - \\
\hline \multirow[t]{2}{*}{3} & $\begin{array}{l}\text { Acyanotic } \\
\text { Normal }\end{array}$ & $\because$ & $\cdots$ & 2 & $\underline{3}^{3}$ & 5 & 45 & 95 & 105 & 105 & 100 & 95 & 82 & 75 & 65 & - & - & - \\
\hline & Normal & $\ddot{\cdots}$ & $\because$ & $\overline{1}$ & -1 & 1 & -1 & - 1 & $\overline{1}_{1}$ & -1 & $\overline{2}$ & 3 & 3 & 6 & $\overline{13}$ & $\overline{22}$ & 22 & $\overline{22}$ \\
\hline \multirow[t]{2}{*}{4} & Acyanotic & .. & .. & - & - & - & - & - & - & & & & & 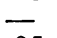 & & 二 & $=$ & 22 \\
\hline & & $\cdots$ & .. & 1 & 2 & 3 & 5 & 16 & 95 & 105 & 105 & 105 & 100 & 95 & 2 & - & - & \\
\hline \multirow{3}{*}{5} & Cyan & . & . & 1 & 3 & 75 & 98 & 98 & 95 & 95 & 95 & 95 & 95 & 90 & 80 & - & - & - \\
\hline & & .. & .. & 1 & & 4 & 25 & 105 & 105 & 100 & 100 & 95 & 90 & 70 & & - & - & - \\
\hline & $\int$ Cyanc & .. & . & 60 & 100 & $\begin{array}{r}100 \\
37\end{array}$ & 100 & 88 & 88 & 80 & 80 & 80 & 70 & 62 & 5 & - & - & 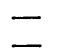 \\
\hline \multirow{2}{*}{7} & $\left\{\begin{array}{l}\text { Acyanotic } \\
\text { Normal }\end{array}\right.$ & $\begin{array}{l}\cdots \\
\ldots\end{array}$ & $\because$. & 35 & $\begin{array}{r}3 \\
105\end{array}$ & $\begin{array}{r}37 \\
105\end{array}$ & $\begin{array}{l}100 \\
105\end{array}$ & $\begin{array}{l}110 \\
105\end{array}$ & $\begin{array}{l}110 \\
105\end{array}$ & $\begin{array}{l}105 \\
105\end{array}$ & $\begin{array}{l}105 \\
100\end{array}$ & 100 & 100 & $\begin{array}{l}92 \\
92\end{array}$ & $\begin{array}{l}82 \\
92\end{array}$ & - & & \\
\hline & Cya & .. & .. & 1 & 2 & 100 & 4 & 50 & 82 & 88 & 88 & 82 & $\begin{array}{l}92 \\
68\end{array}$ & 60 & 50 & - & - & - \\
\hline \multirow[t]{3}{*}{8} & Acyanotic & .. & $\ldots$ & 1 & 3 & 100 & 105 & 105 & 100 & 100 & 100 & 98 & 88 & 82 & 80 & - & - & 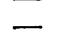 \\
\hline & Norm & $\ldots$ & .. & $\sqrt{0}$ & - & 20 & & & $\longrightarrow$ & & & & & $\overline{75}$ & & 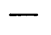 & - & \\
\hline & & $\cdots$ & . & 2 & 5 & 32 & 100 & $\begin{array}{r}100 \\
88\end{array}$ & $\begin{array}{r}100 \\
88\end{array}$ & $\begin{array}{r}100 \\
88\end{array}$ & $\begin{array}{l}98 \\
68\end{array}$ & 88 & 82 & 75 & 45 & - & - & 二 \\
\hline \multirow[t]{2}{*}{9} & $\begin{array}{l}\text { Acy } \\
\text { Nor }\end{array}$ & $\cdots$ & $\cdots$ & 1 & 16 & $\begin{array}{r}88 \\
9\end{array}$ & $\begin{array}{r}100 \\
98\end{array}$ & $\begin{array}{r}88 \\
105\end{array}$ & $\begin{array}{r}88 \\
105\end{array}$ & $\begin{array}{r}88 \\
105\end{array}$ & $\begin{array}{r}68 \\
105\end{array}$ & $\begin{array}{r}50 \\
100\end{array}$ & $\begin{array}{r}42 \\
100\end{array}$ & $\begin{array}{r}40 \\
100\end{array}$ & 9 & 二 & - & - \\
\hline & $\begin{array}{l}\text { No } \\
\text { Cya }\end{array}$ & $\because$. & $\because$. & 1 & 5 & 88 & 88 & 88 & 88 & 80 & 68 & 64 & 60 & 50 & 4 & - & - & 二 \\
\hline \multirow[t]{2}{*}{10} & Acyan & .. & $\ldots$ & 1 & 2 & 5 & 92 & 100 & 100 & 100 & 100 & 98 & 92 & 88 & 82 & - & - & - \\
\hline & Nor & $\cdots$ & $\cdots$ & 1 & -1 & 2 & 2 & 3 & 4 & 23 & 34 & 34 & 34 & 24 & 22 & 22 & $2 ?$ & $\bar{z}$ \\
\hline \multirow[t]{3}{*}{11} & Acs & 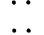 & 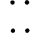 & 1 & - & - & 2 & 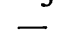 & 4 & 2. & 工 & 24 & 24 & 24 & 22 & -2 & 22 & \\
\hline & & $\ldots$ & & 2 & 2 & 4 & 24 & 110 & 110 & 105 & 100 & 100 & 98 & 92 & 8 & - & - & - \\
\hline & Cy & . & . & 1 & 1 & 1 & 1 & 2 & 4 & 17 & 32 & 40 & 40 & 32 & 52 & - & - & - \\
\hline \multirow[t]{2}{*}{12} & Ac & .. & . & 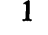 & 1 & 2 & 4 & 44 & 82 & 88 & 82 & 80 & 68 & 64 & 60 & - & - & - \\
\hline & No & & ${ }^{\circ}$ & & & & & & & & & & & & & - & 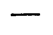 & \\
\hline \multirow[t]{2}{*}{20} & $\left\{\begin{array}{l}\text { Cyanotic } \\
\text { Normal }\end{array}\right.$ & .. & . & $\begin{array}{l}1 \\
1\end{array}$ & $\begin{array}{l}2 \\
2\end{array}$ & $\begin{array}{l}5 \\
2\end{array}$ & $\begin{array}{l}93 \\
80\end{array}$ & $\begin{array}{l}112 \\
105\end{array}$ & $\begin{array}{l}127 \\
105\end{array}$ & $\begin{array}{l}127 \\
105\end{array}$ & $\begin{array}{l}127 \\
100\end{array}$ & $\begin{array}{l}127 \\
100\end{array}$ & $\begin{array}{r}120 \\
98\end{array}$ & $\begin{array}{r}120 \\
93\end{array}$ & $\begin{array}{r}105 \\
88\end{array}$ & 二 & 二 & 二 \\
\hline & & & & & & & & & & & & & & & & & & \\
\hline
\end{tabular}

$7 \cdot 8 \mathrm{sec} .=100$ per cent.

packed cell volume in 40 cyanotic patients (Fig. 2A), patients with considerable increase in the packed cell volume usually showed gross impairment of thromboplastin generation. The relation of the hæmoglobin level to peak percentage thromboplastin generation was similar (Fig. 2B). Most of the cyanotic patients with extreme increase in the packed cell volume had grossly impaired thromboplastin generation, but there were 3 exceptions: Patients No. 18, 20, and 38, in whom the packed cell volumes were 55,54 , and 84 per cent, had increased thromboplastin generation achieving peaks of 124,127 , and 114 per cent. Unless the packed cell volume was above 65 per cent, correction for high packed cell volume and reduced plasma volume made little difference to levels of thromboplastin generation in the group with cyanotic congenital heart disease. Above 65

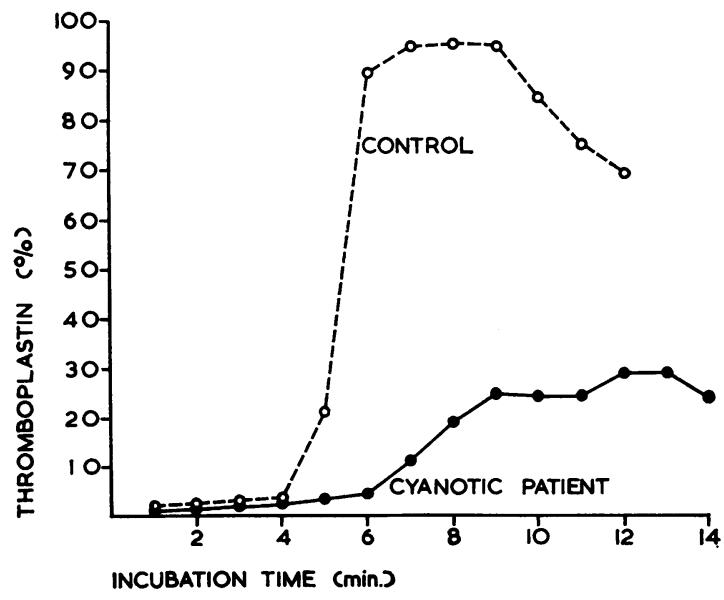

FIG. 1.-Thromboplastin generation in a control and in a patient with cyanotic congenital heart disease. In this patient correction was made for the concentration of citrate (see text). 


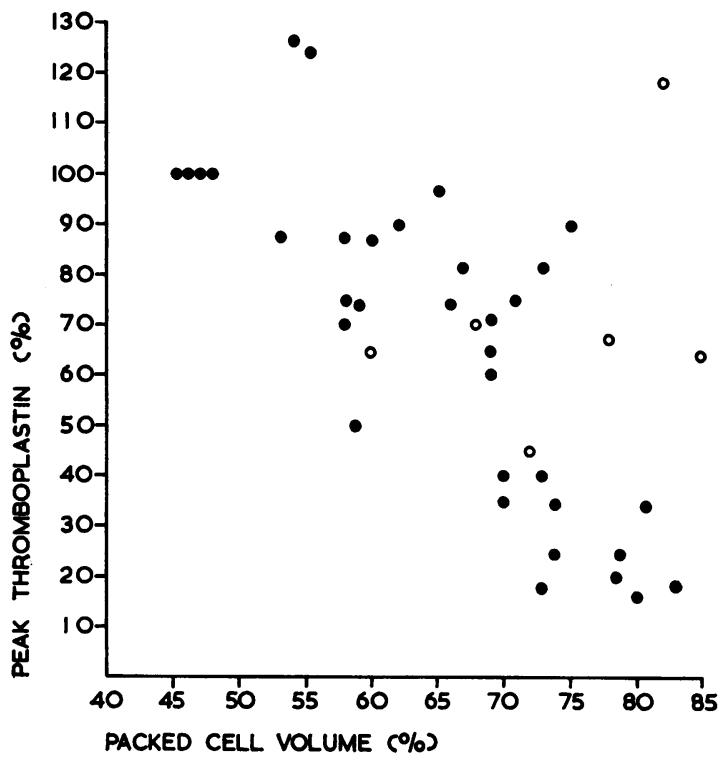

FIG. 2.-(A) Peak percentage achieved in the thromboplastin generation test related to packed cell volume in 40 patients with cyanotic congenital heart disease. $=$ readings not corrected for concentration of citrate; $\mathrm{O}=$ readings corrected for concentration of citrate (see text).

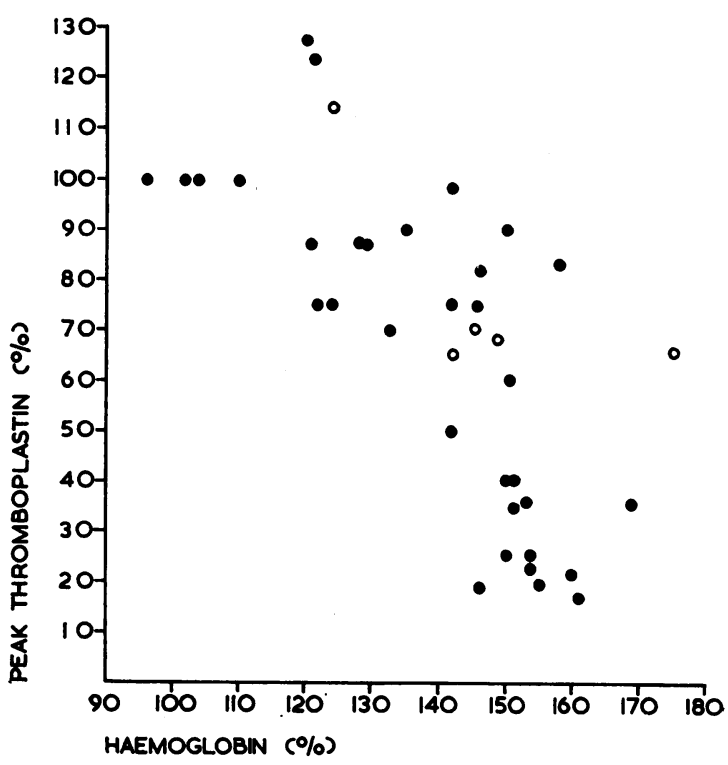

FIG. 2.-(B) Peak percentage achieved in the thromboplastin generation test related to hæmoglobin percentage in 38 patients with cyanotic congenital heart disease. $=$ readings not corrected for concentration of citrate; $O=$ readings corrected for concentration of citrate (see text).

\section{TABLE III}

Thromboplastin Generation in Patients with Cyanotic Congenital Heart Disease, with and Without Correction for Undue Dilution of Plasma with Sodium Citrate

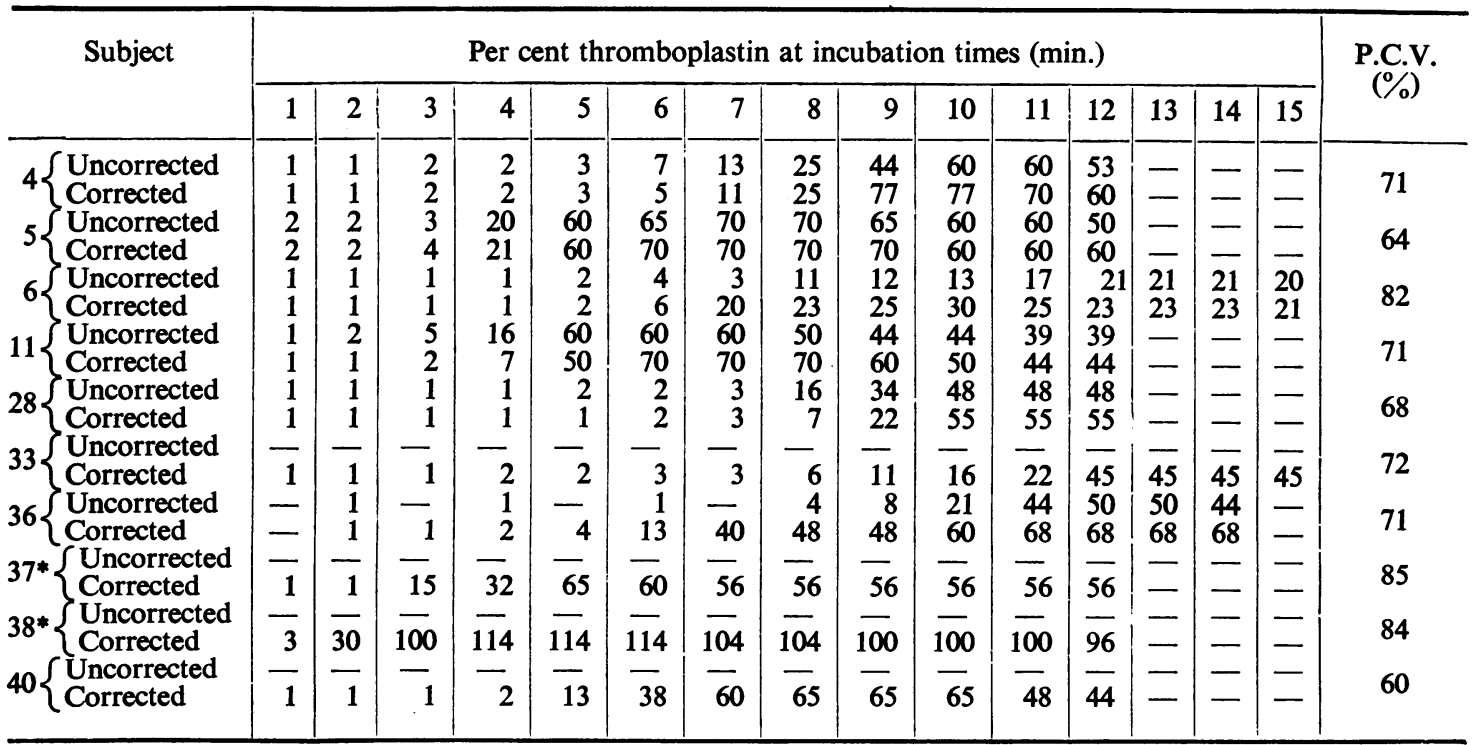

* $7.8 \mathrm{sec} .=100$ per cent. $9 \cdot 5 \mathrm{sec} .=100$ per cent. 
TABLE IV

Age, Sex, Hamoglobin, Packed Cell Volume, Fibrinogen; Platelet Count, Platelet Stickiness, and Peak Thromboplastin Generation Per Cent, in Patients with Primary Polycythemia and Cor Pulmonale

\begin{tabular}{|c|c|c|c|c|c|c|}
\hline $\begin{array}{l}\text { Patient, sex, } \\
\text { and age (yr.) }\end{array}$ & $\mathrm{Hb}(\%)$ & P.C.V. $(\%)$ & $\begin{array}{c}\text { Fibrinogen } \\
\text { ml. in } 2 \mathrm{ml} . \\
\text { plasma }\end{array}$ & $\begin{array}{l}\text { Platelets/c. mm. } \\
\text { whole blood in } \\
\text { thousands }\end{array}$ & $\begin{array}{c}\text { Platelets } \\
\text { stickiness } \\
\text { (\% remaining } \\
\text { at } 20 \text { min.) }\end{array}$ & $\begin{array}{l}\text { Peak thrombo- } \\
\text { plastin } \\
\text { generation }(\%)\end{array}$ \\
\hline \begin{tabular}{lll} 
Primary \\
\multicolumn{3}{c}{ Polycythamia } \\
A & M & 36 \\
B & F & 55 \\
C & F & 71 \\
D & F & 61 \\
E & M & 73 \\
F & M & 51 \\
G & M & 57
\end{tabular} & $\begin{array}{r}127 \\
140 \\
112 \\
92 \\
100 \\
115 \\
113\end{array}$ & $\begin{array}{l}53 \\
66 \\
54 \\
50 \\
58 \\
52 \\
51\end{array}$ & $\begin{array}{l}0.05 \\
0.07 \\
0.06 \\
0.06 \\
0.06 \\
0.05 \\
0.06\end{array}$ & $\begin{array}{l}225 \\
232 \\
239 \\
218 \\
306 \\
175 \\
223\end{array}$ & $\begin{array}{l}72 \\
50 \\
72 \\
79 \\
76 \\
81 \\
83\end{array}$ & $\begin{array}{r}110^{*} \\
100^{*} \\
112^{*} \\
120^{*} \\
95^{*} \\
105^{*} \\
110^{*}\end{array}$ \\
\hline 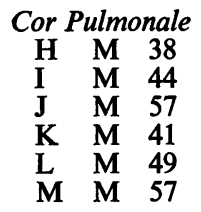 & $\begin{array}{r}75 \\
129 \\
142 \\
112 \\
132 \\
120\end{array}$ & $\begin{array}{l}41 \\
67 \\
63 \\
55 \\
63 \\
53\end{array}$ & $\begin{array}{l}0.05 \\
0.05 \\
0.05 \\
0.09 \\
0.06 \\
0.07\end{array}$ & $\begin{array}{l}183 \\
112 \\
261 \\
193 \\
175 \\
172\end{array}$ & $\begin{array}{l}- \\
- \\
\overline{74} \\
60 \\
70\end{array}$ & $\begin{array}{r}76 \\
80 \\
62 \\
108^{*} \\
88^{*} \\
80^{*}\end{array}$ \\
\hline
\end{tabular}

* Not corrected for P.C.V.

per cent the depression of thromboplastin generation was evident but slightly less marked (Table III).

The findings in patients with cor pulmonale and primary polycythæmia are shown in Table IV. None of the patients with cor pulmonale, or with primary polycythæmia, had extreme increase in the packed cell volume: in the former, thromboplastin generation showed similar impairment to that found in cyanotic congenital heart disease, whereas in the latter it was normal (Fig. 3). Correction for the amount of citrate used, in relation to the packed cell volume, made no significant difference to these findings.

In Patient No. 6, with cyanotic congenital heart disease, who was extensively studied, no evidence was found of Factor V deficiency, the prothrombin consumption ratio was within the normal range, and, using platelet-rich plasma, thrombin generation was normal. Alumina-adsorbed plasma from the patient inhibited a normal thromboplastin generation system by 2 seconds, raising the possibility of an inhibitor. No evidence of Factor $\mathrm{V}$ deficiency has been found in two other patients with very depressed thromboplastin generation. The source of Factor V deficiency plasma was aged oxalated human plasma, and results were confirmed using plasma from a Factor $\mathrm{V}$ deficient patient. In 9 patients with cyanotic heart disease, and 10 normal people, assay of antihæmophilic globulin showed varying readings in the patients (Table $V$ ). One patient (No. 5), in heart failure, had a reading higher than was normal: if this patient is excluded from the analysis, the antihæmophilic globulin levels in

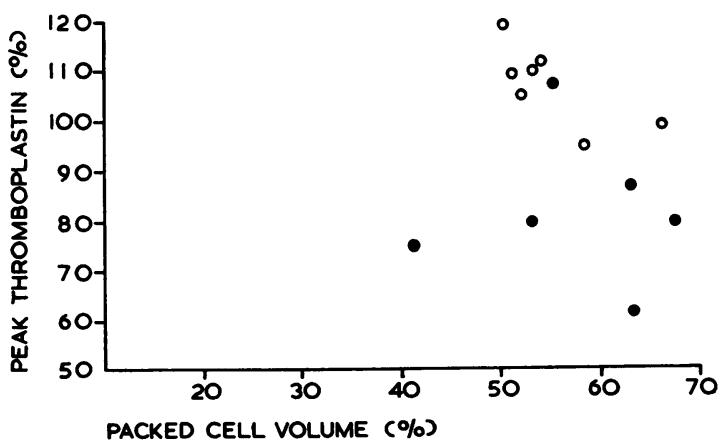

FIG. 3.-Peak percentage achieved in the thromboplastin generation test related to packed cell volume percentage in 7 patients with polycythæmia rubra vera $(O)$ and 6 patients with cor pulmonale (O). 
TABLE V

Antihamophilic Globulin Per Cent (Standard 100\%) in Patients with Cyanotic CongentTal Heart Disease and IN NoRmals

\begin{tabular}{c|c|c|c}
\hline \multirow{2}{*}{ Patient No. } & P.C.V. (\%) & \multicolumn{2}{|c}{ Antihæmophilic globulin (\%) } \\
\cline { 2 - 4 } & & Patient & Control \\
\hline 1 & 76 & 167 & 100 \\
4 & 71 & 146 & 180 \\
& & & 100 \\
$5 *$ & 64 & 265 & 168 \\
6 & 82 & 60 & 78 \\
15 & 61 & 72 & 220 \\
20 & 55 & 80 & 100 \\
28 & 69 & 55 & 140 \\
36 & 69 & 108 & 124 \\
40 & 60 & 100 & 124 \\
\hline
\end{tabular}

* Patient in heart failure.

this group of patients with cyanotic congenital heart disease are significantly lower than in normal people.

The investigation to determine the cause of the impairment of thromboplastin generation in 13 patients with cyanotic congenital heart disease showed that system (i) (see method) lessened the peak percentage of thromboplastin generated. The second system (ii) lowered further the peak percentage of thromboplastin generation. However, system (iii) gave a normal peak generation of thromboplastin, and the completely normal system (iv) also showed a normal thromboplastin generation. These findings suggest that the cause of impaired thromboplastin generation, in patients with cyanotic congenital heart disease, is in the plasma and not the serum.

\section{Discussion}

Unusual bleeding is known to complicate surgery in patients with cyanotic congenital heart disease (Blalock, 1948). This complication occurs without the use of extracorporeal circulation, which itself introduces additional problems. Severe hæmorrhage followed a first thoracotomy on 20 of the first 240 patients with cyanotic congenital heart disease operated on by Sir Russell Brock and Sir Thomas Holmes Sellors between 1949 and 1952; it was from the chest wall and pleura and was not due to bleeding from major vessels. None of these patients had a history of spontaneous hæmorrhage or purpura, but in two of the patients severe bleeding had previously followed dental extraction. In the present group of 40 patients with cyanotic congenital heart disease, there was no history of spontaneous bleeding which might be expected if one of the known deficiencies of clotting was present. However, 6 of the patients had had severe bleeding after such interference as dental extraction, thoracotomy, and partial gastrectomy. Thus the clotting mechanism, which is otherwise sufficient in these patients, seems often to be inadequate to control bleeding after operation and trauma.

The results of previous investigations of blood coagulation in patients with cyanotic congenital heart disease have revealed many different abnormalities. Thrombocytopenia, low plasma fibrinogen, and defective clot retraction were found by Hartmann (1952), hypoprothrombinæmia by Favre-Gilly, Bret, and Borel-Milhet (1951), and a quantitative platelet abnormality with Factor V deficiency by Alagille et al. (1958). These abnormalities, by themselves, seemed inadequate to account for the tendency to serious post-operative hæmorrhage. In the present investigation low plasma fibrinogen and low platelet counts were conspicuous in the patients with cyanotic congenital heart disease. However, impairment of thromboplastin generation, a previously unrecognized abnormality, was most frequently encountered; it occurred in 21 of the 40 patients with cyanotic 
congenital heart disease. It was closely related to the degree of increase in the packed cell volume and hæmoglobin; cases with the most extreme impairment of thromboplastin generation had the highest packed cell volumes and hæmoglobin level. The lower levels of thromboplastin generation achieved in patients with severe secondary polycythæmia were not artificially produced as a result of reduced plasma volume; after correction of citrate concentration, severe impairment was still evident. Impaired thromboplastin generation of the degree that has been found in these patients with cyanotic congenital heart disease, together with fibrinogenopenia, and thrombocytopenia, appears likely to account for their bleeding tendency at the time of operation and trauma.

The cause of impaired thromboplastin generation in patients with cyanotic congenital heart disease remains uncertain. Factor V, antihæmophilic globulin (Factor 8) and Christmas Factor (9), are necessary for the formation of plasma thromboplastin, and deficiency of these may cause a hæmorrhagic diathesis. In 3 patients, with extremely depressed generation of thromboplastin, no deficiency of Factor V was found. Antihæmophilic globulin levels were widely scattered throughout the range of normal, but with a number below the average, which may be significant in relation to the demonstrated depression of thromboplastin generation. In only one patient, who was in congestive heart failure, was the level of antihæmophilic globulin higher than normal. However, no single factor was so deficient to cause such depression of thromboplastin generation, and it appears that in these patients with cyanotic congenital heart disease, impairment of thromboplastin generation is multifactorial in origin, and part of a pan-deficiency of clotting factors. Of the patients who had the most severely depressed thromboplastin generation, 22 had platelet counts that were low, and 22 had fibrinogen levels below average.

Both in the patients with cor pulmonale, and in those with primary polycythæmia, there was an increase in the packed cell volume and in the level of hæmoglobin. Thromboplastin generation was persistently normal in patients with primary polycythæmia, but depressed in those with cor pulmonale. This suggests that chronic hypoxia, which is common to patients with cyanotic congenital heart disease and cor pulmonale, may be responsible for impaired blood coagulation.

The thromboplastin generation test has proved useful in predicting the occurrence of postoperative hæmorrhage in patients with cyanotic congenital heart disease. This test was frequently abnormal when cruder tests of blood coagulation were normal. Six patients in the present series had serious bleeding after operation. Their hæmoglobin was above 135 per cent with correspondingly impaired thromboplastin generation. The 20 cyanotic patients who had catastrophic postoperative bleeding, but were operated on before this investigation was begun, also had hæmoglobin levels greater than 135 per cent. If thromboplastin generation is abnormally low before operation, or, as an indirect guide, if the hæmoglobin level is particularly high, then post-operative bleeding must be considered a possibility. It may not inevitably occur: local factors, and particularly the presence of widespread adhesions from previous operations, are important contributory factors. Of 17 consecutive patients undergoing second operations (by R.C.B.), 10 had severe hæmorrhage, and of these 5 died. Of the 5 who died, 3 had had thromboplastin generation tests, and all of these had severely impaired generation.

There is a small group of patients with cyanotic congenital heart disease, and extreme increase of the packed cell volume, who have normal or increased thromboplastin generation. In Fig. 2B there are 3 patients with a hæmoglobin over 130 per cent and normal thromboplastin generation. Such patients have, as might be expected, a tendency to post-operative thrombosis which occurred in 2 of these 3 patients.

Extracorporeal circulation introduces additional problems with regard to blood coagulation and may further interfere with an already faulty clotting mechanism, thereby aggravating the likelihood of hæmorrhage in these patients. On the other hand it may be beneficial by providing an exchange transfusion of fresh blood which contains necessary clotting factors. As a result of these conflicting effects it is difficult to predict the occurrence of hæmorrhage after the use of extracorporeal circulation. The thromboplastin generation test may usefully predict the tendency to hæmorrhage and this risk may be lowered by the transfusion of fresh blood. 


\section{SUMMARY}

Blood coagulation has been studied in 40 patients with cyanotic congenital heart disease, 10 with acyanotic congenital heart disease, 7 with polycythæmia rubra vera, 6 with cor pulmonale, and 9 normal people.

No abnormality was found in patients with acyanotic congenital heart disease or normal people. In the cyanotic patients there was a tendency for fibrinogen deficiency and thrombocytopenia, but the most frequently encountered abnormality was depression of thromboplastin generation. The degree of impairment of thromboplastin generation was greatest in the patients with the greatest increase in hæmoglobin. Patients with primary polycythæmia did not show abnormal thromboplastin generation, but patients with cor pulmonale did.

The relationship of this finding to post-operative hæmorrhage in cyanotic patients is discussed. It is thought that the cause of the impaired thromboplastin generation is likely to be important in causing serious bleeding and that the test is useful in predicting the occurrence of post-operative hæmorrhage.

We thank Drs. R. G. Macfarlane, F.R.S., and Rosemary Biggs for helpful criticism; the physicians and surgeons of Guy's, the Middlesex, and the National Heart Hospitals, who referred their patients for study, and particularly Sir Russell Brock, Sir Thomas Holmes Sellors, and Dr. Dennis Deuchar, who kindly allowed us access to their records.

\section{REFERENCES}

Alagille, D., Heim de Balsac, R., Guéry, J., Passelecq, J., Blondeau, P., and Dubost, C. (1958). Les thrombopathies associées aux cardiopathies congénitales (étude de l'hémostase dans cinquante cas). Rev. franc. Étud. clin. biol., 3, 322 .

Biggs, R., and Douglas, A. S. (1953). The thromboplastin generation test. J. clin. Path., 6, 23.

, and Macfarlane, R. G. (1957a). Human Blood Coagulation and its Disorders, 2nd ed., p. 401. Blackwell Scientific Publications, Oxford.

$\longrightarrow$, and $-(1957 \mathrm{~b})$. p. 407.

- , and - (1957c). p. 406.

- , and - (1957d). p. 398.

$\longrightarrow$, and - (1962a). 3rd ed., p. 404.

$\longrightarrow$, and $-(1962 b)$. 3rd ed., p. 412.

Blalock, A. (1948). Surgical procedures employed and anatomical variations encountered in the treatment of congenital pulmonic stenosis. Surg. Gynec. Obstet., 87, 385.

Dacie, J. V. (1956). Practical Hamatology, 2nd ed., p. 8. Churchill, London.

Favre-Gilly, J., Bret, J., and Borel-Milhet, J. (1951). Un trouble inattendu de la coagulation dans la maladie bleue; l'hypoprothrombinémie. Sang, 22, 278.

Hartmann, R. C. (1952). A hemorrhagic disorder occurring in patients with cyanotic congenital heart disease. Bull. Johns Hopk. Hosp., 91, 49.

Lee, R. I., and White, P. D. (1913). A clinical study of the coagulation time of blood. Amer. J. med. Sci., 145, 495 .

McDonald, L., and Edgill, M. (1958). Dietary restriction and coagulability of the blood in ischæmic heart-disease. Lancet, 1, 996.

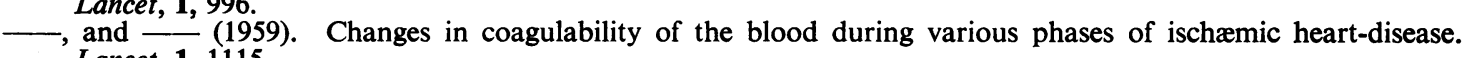
Lancet, 1, 1115.

Pitney, W. R., and Dacie, J. V. (1953). A simple method of studying the generation of thrombin in recalcified plasma; application in investigation of hæmophilia. J. clin. Path., 6, 9.

Somerville, J., and McDonald, L. (1960). The bleeding tendency in cyanotic congenital heart disease. In Proceedings of the British Cardiac Society. Brit. Heart J., 22, 589.

Warren, R., and Wysocki, A. (1958). Assay of heparin in blood: a critique. Surgery, 44, 435.

Wright, H. P. (1941). The adhesiveness of blood platelets in normal subjects with varying concentrations of anticoagulants. J. Path. Bact., 53, 255. 